Article

\title{
Silicon-Mediated Physiological and Agronomic Responses of Maize to Drought Stress Imposed at the Vegetative and Reproductive Stages
}

\author{
Dongfeng Ning ${ }^{1}$, Anzhen Qin ${ }^{1}{ }^{*}$, Zhandong Liu ${ }^{1}$, Aiwang Duan ${ }^{1}$, Junfu Xiao ${ }^{1}$, Jiyang Zhang ${ }^{1}$, \\ Zugui Liu ${ }^{1}$, Ben Zhao ${ }^{1}$ and Zhanjun Liu ${ }^{2, *}$ \\ 1 Key Laboratory of Crop Water Use and Regulation, Ministry of Agriculture and Rural Affairs, Institute of \\ Farmland Irrigation, Chinese Academy of Agricultural Sciences, Xinxiang 453002, China; \\ ningdongfeng@caas.cn (D.N.); liuzhandong@caas.cn (Z.L.); duanaiwang@caas.cn (A.D.); \\ xiaojunfu@caas.cn (J.X.); zhangjiyang@caas.cn (J.Z.); liuzugui@caas.cn (Z.L.); zhaoben@caas.cn (B.Z.) \\ 2 College of Natural Resources and Environment, Northwest A \& F University, Yangling 712100, China \\ * Correspondence: qinanzhen@caas.cn (A.Q.); zjliu@nwsuaf.edu.cn (Z.L.)
}

Received: 21 July 2020; Accepted: 30 July 2020; Published: 5 August 2020

check for updates

\begin{abstract}
Silicon (Si) enhances maize resistance to drought. While previous studies have mainly focused on the seedling stage, the mediation of drought stress by Si imposed at the vegetative and reproductive stages has been rarely investigated. A soil-column experiment was thus conducted under a rainproof shelter to quantify the effect s of Si application on the physiological and agronomic responses of maize to drought stress imposed at the 6-leaf (D-V6), 12-leaf (D-V12), and blister (D-R2) stages. The observed parameters included plant growth, photosynthesis, osmolytes, antioxidant activity, and grain yield. The results showed that drought stress strongly decreased the leaf area, leaf water content, photosynthetic rate, chlorophyll content, and antioxidant activity (superoxide dismutase (SOD), peroxidase (POD), and catalase (CAT)) and markedly increased lipid peroxidation. D-V6, D-V12, and D-R2 decreased grain yields by $12.9 \%, 28.9 \%$, and $44.8 \%$, respectively, compared to the well-watered treatment (CK). However, Si application markedly increased leaf area, chlorophyll content, photosynthetic rate, osmolyte content, and enzymatic antioxidant activities (SOD, POD, and CAT), and decreased malondialdehyde (MDA) and superoxide radical accumulation, ultimately improving maize yields by $12.4 \%, 69.8 \%$, and $80.8 \%$, respectively, compared to the non-Si treated plants under drought stress at the V6, V12, and R2 stages. Furthermore, maize yields had a significant positive correlation with chlorophyll content and SOD and POD activity during the three stages. Our findings suggest that Si-induced changes in chlorophyll content and antioxidant activity might constitute important mechanisms for mitigating drought stress. In conclusion, this study provides physico-biochemical evidence for the beneficial role of $\mathrm{Si}$ in alleviating drought-induced yield reduction in maize, particularly during the late vegetative or early reproductive stages. Thus, $\mathrm{Si}$ application constitutes an effective approach for improving maize yield in rain-fed agricultural systems.
\end{abstract}

Keywords: maize; silicon; drought stress; photosynthesis; antioxidant defense

\section{Introduction}

Drought significantly threatens crop productivity and food security worldwide, particularly in arid and semiarid regions [1]. Unfortunately, the severity of drought is expected to increase in the future under predicted climate change scenarios [2] and is anticipated to seriously hamper crop growth on more than $50 \%$ of the Earth's arable land by 2050 [3]. Thus, effective strategies for improving plant resistance to drought stress are urgently required [4]. 
Silicon ( $\mathrm{Si}$ ) is considered to be one of the most important exogenous compounds that offers a cost-effective approach for mitigating biotic (e.g., plant disease and pest attacks) or abiotic (e.g., salt, drought, freezing, and heavy metal toxicity) stresses [5-7]. Numerous studies have demonstrated that $\mathrm{Si}$ is beneficial for alleviating drought stress in various species, including wheat [8], maize [9], soybean [10], rice [11], sorghum [12], and mango [13]. The enhanced drought resistance associated with $\mathrm{Si}$ is mainly believed to be related to reduced transpiration capacity [9], increased water uptake by the roots [14], the alleviation of oxidative damage [15], and decreased osmotic potential [12]. However, studies on the effects of Si application on plant transpiration and stomatal conductance under drought stress have contradictory findings $[9,14,16]$ and the fundamental mechanisms for Si-mediated drought tolerance have not been sufficiently elucidated.

Maize (Zea mays L.) is an important staple food crop in China and many other countries [17]. However, seasonal drought stress (DR) usually leads to a $20-50 \%$ reduction in maize yield and has become the largest limitation to maize production in recent decades $[18,19]$. Moreover, the severity, occurrence, and duration of drought significantly impaired maize growth and development, markedly lowering grain yields $[20,21]$. As a Si accumulator, maize has been widely used for studying the impacts of Si under environmental stresses [22]. Although many studies have assessed the effects of Si on plant resistance to DR, most of those mainly focused on the seedling stage. Little information is available on the influence of $\mathrm{Si}$ additions on maize growth under imposed DR at other critical development stages. In this study, a soil column experiment was carried out during a life cycle of maize with the objectives of (1) characterizing the agronomic and physiological responses of summer maize to DR at the 6-leaf (V6), 12-leaf (V12), and blister (R2) stages, and (2) investigating the effects of Si application on ameliorating plant growth, physiological properties, and grain yield in maize under DR imposed at the V6, V12, and R2 stages. The results should inform the sustainable management of rain-fed maize cropping systems.

\section{Materials and Methods}

\subsection{Experimental Site and Treatments}

A soil column field experiment was conducted under a water-proof shelter at the Guangli Irrigation District, Qinyang, China ( $35^{\circ} 06^{\prime} \mathrm{N}, 112^{\circ} 45^{\prime} \mathrm{E}, 150 \mathrm{~m}$ a.s.l.). The experiment was implemented from June to September 2017. This area has a semi-humid monsoon climate, and the average temperature and precipitation during the growing season (June to September) are $25^{\circ} \mathrm{C}$ and $300 \mathrm{~mm}$, respectively (data obtained from 2000-2017). The experimental soil is derived from alluvial sediments from the Yellow River and is classified as Aquic Ustochrept according to USDA soil taxonomy. The selected soil is a typical soil in the North China Plain with a sandy loam texture. The physico-chemical properties of the test soil are as follows: $\mathrm{pH}-8.16$, organic matter- $-16.8 \mathrm{~g} \mathrm{~kg}^{-1}$, total nitrogen $-1.12 \mathrm{~g} \mathrm{~kg}^{-1}$, inorganic $\mathrm{N}-24.7 \mathrm{mg} \mathrm{kg}^{-1}$, Olsen-P—10.9 $\mathrm{mg} \mathrm{kg}^{-1}$, available potassium—277 mg kg-1, available silicon-328 mg kg $\mathrm{m}^{-1}$, bulk density-1.35 $\mathrm{g} \mathrm{cm}^{-3}$, and filed capacity-23.5\%.

A maize seedling (DH 605, a dominant hybrid in the North China Plain) was planted in the middle of each column bucket (Figure 1). DH 351 was used as female parent and DH 382 as male parent. The female parent was selected from "DH158/107" as the basic material, and the male parent was selected from the foreign hybrid X1132, which was bred from a multi-generation inbred line.

Each soil column system included two columned buckets made of stainless steel, with one larger bucket $(32 \mathrm{~cm}$ in diameter and $100 \mathrm{~cm}$ deep) buried into the soil and another smaller bucket $(30 \mathrm{~cm}$ in diameter and $100 \mathrm{~cm}$ deep) inserted into the larger one (Figure 1). To make the soil column more similar to field conditions, each soil column was filled with a $5 \mathrm{~cm}$ thick sand layer at the bottom, and the remaining 5-95 cm soil layer was packed with 0-90 cm of field soil layers typical of the region, which allows for robust root system growth during the experimental period. According to the fertilization practices of the region, $0.2 \mathrm{~g} \mathrm{~N}, 0.05 \mathrm{~g} \mathrm{P}_{2} \mathrm{O}_{5}$, and $0.10 \mathrm{~g} \mathrm{~K}_{2} \mathrm{O}$ per $\mathrm{kg}$ dry soil (calculated based on 0-30 $\mathrm{cm}$ soil dry weight) were applied to meet the maize nutrient requirements. $\mathrm{N}, \mathrm{P}$, and $\mathrm{K}$ were supplied 
by urea $(46 \% \mathrm{~N})$, superphosphate $\left(18 \% \mathrm{P}_{2} \mathrm{O}_{5}\right)$, and potassium sulfate $\left(50 \% \mathrm{~K}_{2} \mathrm{O}\right)$, respectively. All $\mathrm{P}$ and $\mathrm{K}$ fertilizers were applied as basal fertilizer, while the $\mathrm{N}$ fertilizer was split, using one third at the seedling stage and two thirds at the jointing stage. Weeding and topdressing of the nitrogen were done by hand.
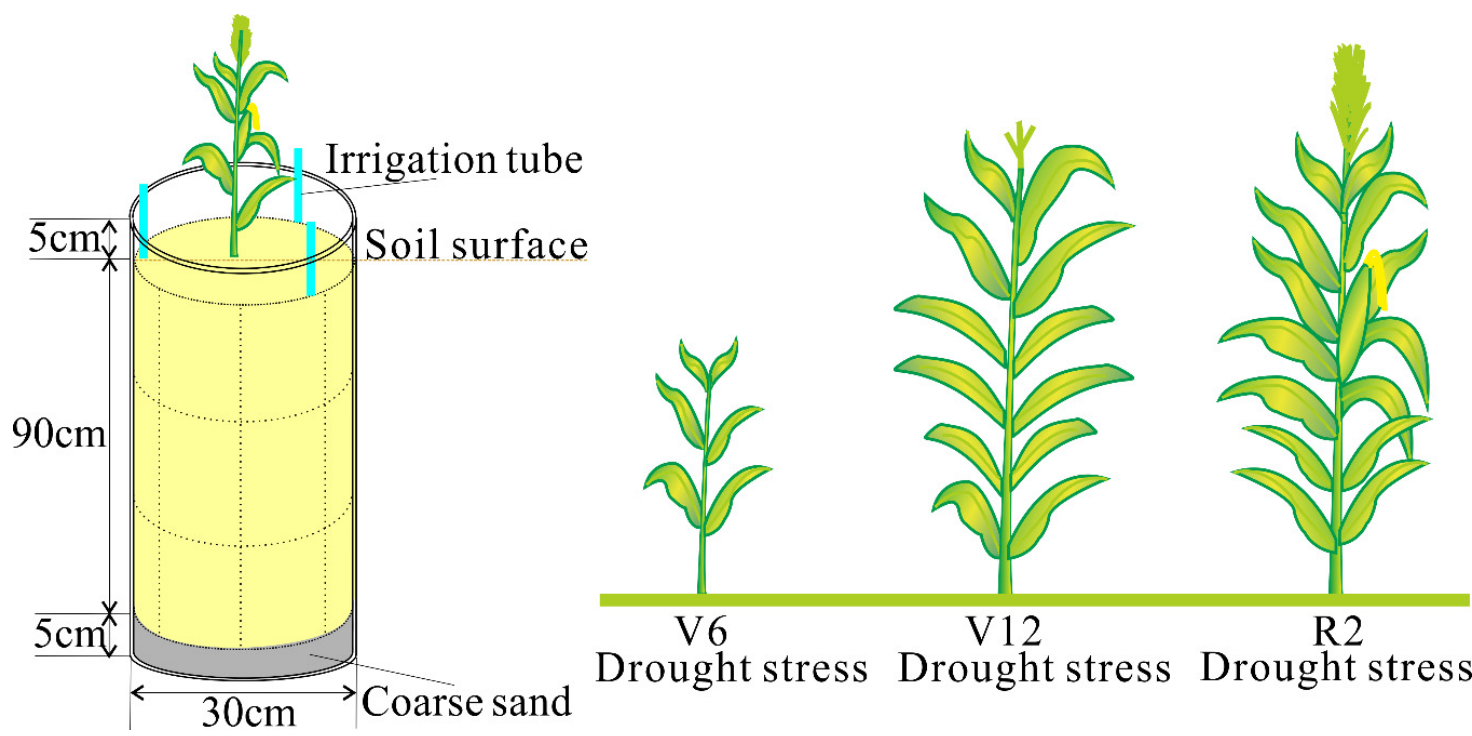

Drought stress Drought stress Drought stress

Figure 1. Diagram of an experimental column and the three drought stress periods during the 6-leaf (V6), 12-leaf (V12), and blister (R2) stages.

The experimental treatments included two Si-fertilization rates and three drought-imposed stages. The experimental were investigated in the complete randomized block design. The two Si-fertilization levels included 0 (-Si) and $0.06 \mathrm{mg} \mathrm{Si} \mathrm{kg}^{-1}$ dry soil (+Si, calculated based on 0-30 cm soil dry weight), and $\mathrm{Si}$ fertilizer was supplied as $\mathrm{Na}_{2} \mathrm{SiO}_{3} \cdot 9 \mathrm{H}_{2} \mathrm{O}$, which was applied as basal fertilizer. Control plants were treated with an equivalent $\mathrm{Na}$ amount of $\mathrm{Na}_{2} \mathrm{SO}_{4}$. Three drought-imposed stages, including the V6 (early vegetative), V12 (late vegetative), and R2 (early reproductive) stages, were separately subjected to moderate drought stress for a duration of $7 \mathrm{~d}$ (Figure 1), corresponding to $50 \%$ of field capacity. For all irrigation treatments, drought levels for potted plants were kept at the same levels, except the non-drought or well-watered treatment. Otherwise, all plants were well-watered outside of the drought periods. A soil water level of $80 \%$ field capacity constituted well-watered conditions and was designed as the control (CK). Therefore, it was guaranteed that all variables were compared at the same level of drought. In this study, the CK treatments were replicated 15 times, and each drought stress treatment was replicated nine times with a total 84 pots. Soil water content was determined gravimetrically by weighing the soil columns and then applying supplemental irrigation every day or every two days depending on the soil water status, maize growth, and weather conditions. Drought stress was induced by withholding irrigation for 2 or $3 \mathrm{~d}$, and then the corresponding soil columns were weighed and irrigated to maintain soil water content at $50 \%$ field capacity.

\subsection{Sampling and Measurements}

\subsubsection{Leaf Samples}

Leaf samples of each treatment (the third upper fully expanded leaves at the V6 and V12 stages, and the female ear leaf at the R2 stage) were destructively collected from three pots at the end of each drought stress period. These samples were rapidly frozen in liquid nitrogen and then stored at $-80{ }^{\circ} \mathrm{C}$ prior to physiological analysis. Table 1 describes the selected analytical protocols. 
Table 1. Protocol measurements for the indicators selected in this study.

\begin{tabular}{|c|c|c|}
\hline Indicators & Protocol & References \\
\hline Leaf water content (LWC) & $\begin{array}{c}\text { Leaf was oven-dried to constant weight at } 80{ }^{\circ} \mathrm{C} \text { to } \\
\text { determine the dry weight. } \mathrm{LWC} \text { was calculated by } \\
\text { the equation: } \mathrm{LWC}(\%)=100 \times(\text { Leaf fresh weight }- \\
\text { Leaf dry weight }) / \text { Leaf fresh weight }\end{array}$ & [8] \\
\hline Chlorophyll content & $\begin{array}{l}\text { Extracted in } 80 \% \text { acetone solution, filtrate was } \\
\text { measured at } 663 \mathrm{~nm}, 646 \mathrm{~nm} \text { and } 470 \mathrm{~nm}\end{array}$ & [23] \\
\hline Malondialdehyde (MDA) & $\begin{array}{l}\text { Thiobarbituric acid (TBA) method, supernatant was } \\
\text { measured at } 532 \mathrm{~nm}, 450 \mathrm{~nm} \text { and } 600 \mathrm{~nm}\end{array}$ & [24] \\
\hline Superoxide radical $\left(\mathrm{O}_{2}^{\cdot-}\right)$ & Hydroxylamine oxidation method & [25] \\
\hline Proline & Acidic ninhydrin method & [26] \\
\hline Soluble sugar & Anthrone-sulfuric acid method & [23] \\
\hline Soluble protein & Coomassie brilliant blue method. & [23] \\
\hline Superoxide dismutase activity (SOD) & Nitro-blue tetrazolium reduction method & [27] \\
\hline Catalase activity (CAT) & $\begin{array}{l}\text { Measured as the reduction in absorbance at } 240 \mathrm{~nm} \\
\text { due to the reduction in } \mathrm{H}_{2} \mathrm{O}_{2}\end{array}$ & [28] \\
\hline Peroxidase activity (POD) & $\begin{array}{l}\text { Based on the determination of guaiacol oxidation at } \\
\qquad 470 \mathrm{~nm} \text { by } \mathrm{H}_{2} \mathrm{O}_{2}\end{array}$ & [29] \\
\hline $\begin{array}{l}\text { Plant-available } \\
\text { Si content in the soil }\end{array}$ & $\begin{array}{l}\text { Extracted by } 0.25 \mathrm{M} \text { citric acid and analyzed by } \\
\text { silicon molybdenum blue spectrophotometry }\end{array}$ & {$[30]$} \\
\hline $\begin{array}{l}\text { Si content } \\
\text { in plants }\end{array}$ & $\begin{array}{c}\text { Extracted by } 50 \% \mathrm{NaOH} \text {, autoclaved at } 125^{\circ} \mathrm{C} \text { for } 1 \mathrm{~h} \text {, } \\
\text { assayed using silicon molybdenum blue } \\
\text { spectrophotometry }\end{array}$ & [31] \\
\hline
\end{tabular}

\subsubsection{Dry Weight of Biomass and Grain Yield}

At the maturity stage, the leaves, stems, and grains of the remaining six maize plants were harvested separately, and their dry weights were recorded after being oven-dried at $75{ }^{\circ} \mathrm{C}$ until a constant weight was achieved. Subsequently, these tissues were ground and passed through a $0.5 \mathrm{~mm}$ sieve for Si analysis. Yield was expressed on a 14\% moisture basis. Soil samples were collected from three pots at harvesting for chemical analysis, and the analytical protocols are indicated in Table 1.

\subsubsection{Plant Height and Leaf Area}

During each drought stress period, plant height and leaf area were measured. The height from the base of the maize stem to the highest point of the plant was defined as the plant height. The length and width of all fully developed green leaves were measured and the leaf area was calculated (length $\times$ width of leaf $\times 0.75$ ).

\subsubsection{Photosynthetic Rate, Transpiration Rate, and Stomatal Conductance}

On the last day of each drought stress period, the third upper leaves (fully expanded) at the V6 and V12 stages, and the female ear leaves at the R2 stage, were marked. The net photosynthetic rate $(\mathrm{Pn})$, transpiration rate (Tr), and stomatal conductance of the marked leaves were measured between 9.00 and 11.00 a.m. using a portable photosynthesis system (LI-6400, LI-COR., Lincoln, NE, USA).

\subsection{Statistical Analysis}

Analysis of variance (ANOVA) was performed using SPSS 18.0 (SPSS Inc., Chicago, IL, USA). A two-way analysis of variance was initially performed to test drought $\times$ Si interaction within the same stage. One-way analysis of covariance (ANOVA) was also performed individually for drought levels and Si treatments. Means were compared using Tukey's least significance difference (LSD) tests at the $5 \%$ probability level. All figures were illustrated using Origin 8.5 software (OriginLab, Northampton, MA, USA). 


\section{Results}

\subsection{Maize Plant Growth}

Drought stress significantly decreased plant height, leaf area and leaf water content across all developmental periods in comparison to CK, with the exception of the R2 stage for plant height. The effects of drought stress and Si application on leaf area and leaf water content varied among the V6, V12, and R2 stages (Figure 2). Silicon application had little effect on plant height across the drought stress stages, but did significantly increase leaf water content at the V12 and R2 stages and increase leaf area at the R2 stage. Interestingly, the growth of D-V6 (drought-imposed at V6 stage) plants was enhanced after re-watering compared with the CK treatment. Silicon application had no significant effect on plant height, leaf area and leaf water content under the well-watered condition (CK) across the tested growth stages.

\subsection{Photosynthesis and Chlorophyll Content}

Drought stress strongly decreased plant photosynthetic rate, transpiration rate, stomatal conductance (Figure 3), and chlorophyll contents, including chlorophyll a, chlorophyll b, and carotenoids (Figure 4) compared to the control. However, Si fertilization significantly improved the photosynthetic rate, transpiration rate, stomatal conductance, and chlorophyll a and chlorophyll b contents of the maize under drought stress conditions imposed at the V12 and R2 stages, whereas no significant differences were observed for these selected variables at the V6 stage regardless of whether Si was applied or not. In addition, Si application only slightly impacted photosynthesis and the chlorophyll content of maize under well-watered conditions across the selected stages, but this was not statistically significant.

\subsection{Osmotic Solute Contents}

The contents were significantly affected by drought stress and Si addition (Figure 5). Soluble protein and sugar contents were substantially augmented by Si application under drought stress irrespective of the growth stage, but not under well-watered conditions (Figure 5A,B). Drought $\times$ Si interaction was detected significant for soluble protein and sugar contents at R2 stage. Notably, drought stress caused a substantial increase in proline content across the three stages compared with the control conditions. Conversely, Si addition had no effect on proline content in the maize plants when drought stress was imposed at the V6 and V12 stages. Drought $\times$ Si interaction was detected significant for proline at the R2 stage (Figure 5C). Under the control conditions, no significant difference in osmotic solute contents was observed across the three stages with or without Si treatment, with the exception of soluble sugars in the + Si treatment, which were appreciably higher than the - Si treatment at the R2 stage.

\subsection{Superoxide Radicals and Malondialdehyde (MDA) Contents}

Drought stress generally enhanced $\mathrm{O}_{2} \cdot-$ and MDA contents in maize leaves compared to the control conditions (Figure 6). On the contrary, the contents of $\mathrm{O}_{2}^{\cdot-}$ and MDA were remarkably reduced by $\mathrm{Si}$ addition under drought stress conditions, with the exception of $\mathrm{O}_{2}{ }^{--}$in the $\mathrm{V} 6$ stage. In contrast, no significant differences in $\mathrm{O}_{2}^{-}$and MDA contents were observed between the treatments with or without $\mathrm{Si}$ additions under well-watered conditions. Drought $\times$ Si interaction was detected as insignificant for $\mathrm{O}_{2}^{\cdot-}$ and MDA contents at the $\mathrm{R} 2$ stage. 


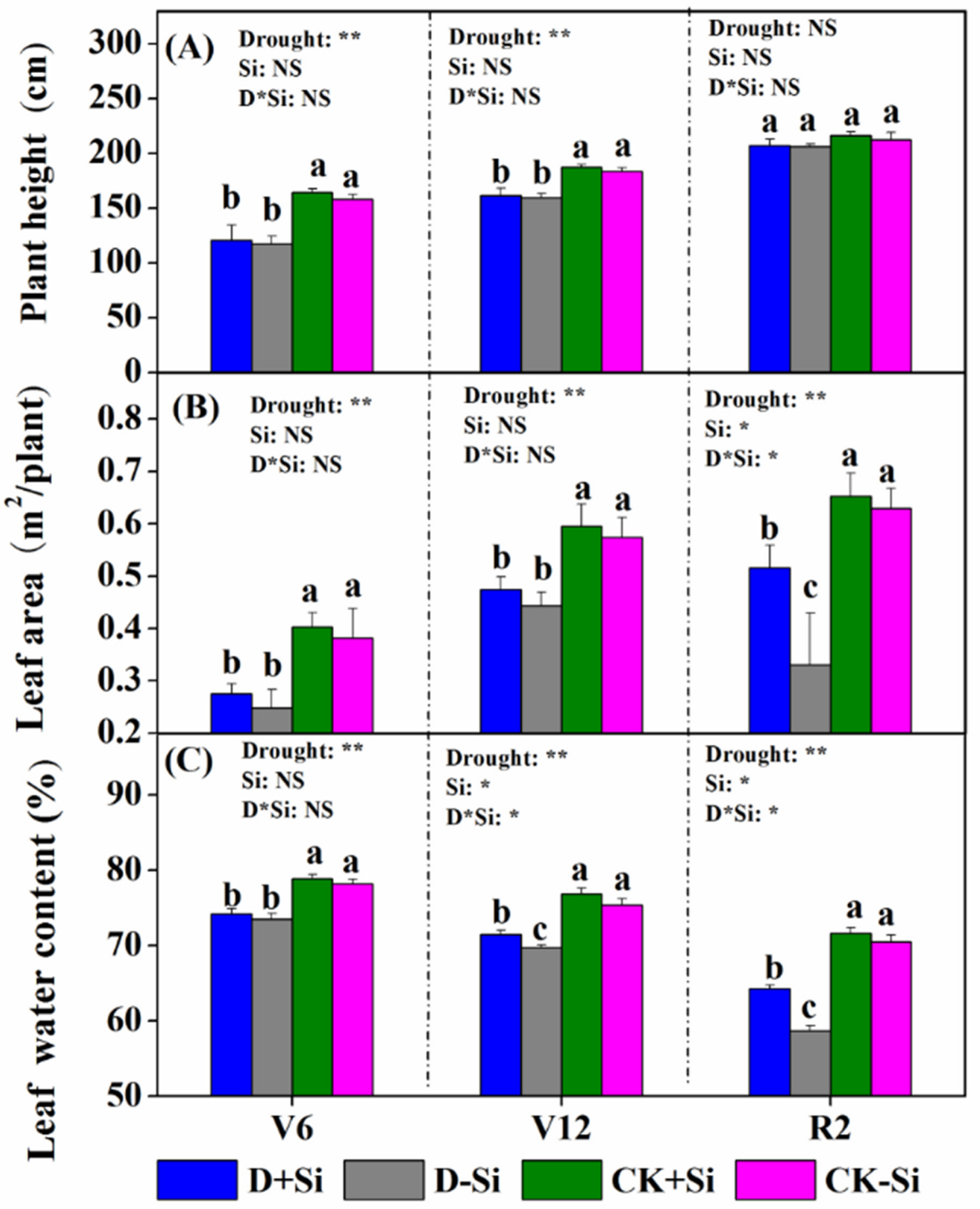

Figure 2. Effect of Si application on plant height (A), leaf area (B) and leaf water content (C) at the V6, V12, and R2 stages. V6, the 6-leaf stage; V12, the 12-leaf stage; R2, the blister stage; +Si, Si addition; -Si, no Si addition; D, drought stress; CK, well-watered control conditions throughout all stages. Data are the means \pm standard errors (SE) of three replicates, where $n=3$ for plant height and leaf area. Different letters $(\mathrm{a}, \mathrm{b}, \mathrm{c})$ above the bars indicate statistical significance $(p \leq 0.05)$. ${ }^{*}$ Significant at $p \leq 0.01$; * significant at $p \leq 0.05 ; \mathrm{NS}$, no significant difference. 


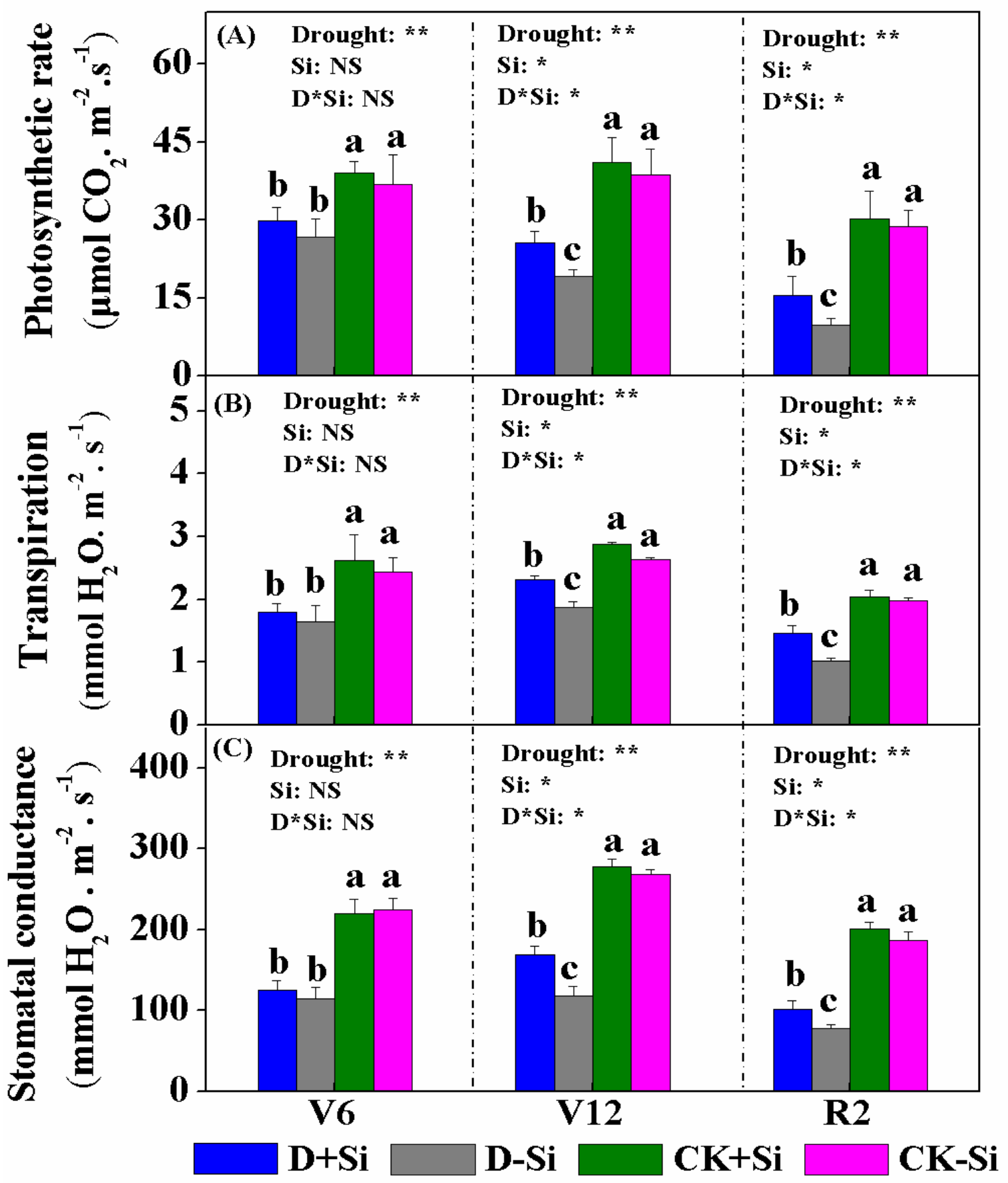

Figure 3. Effect of Si application on photosynthetic rate (Pn, A), stomatal conductance (Sc, B), and transpiration $(\mathrm{Tr}, \mathrm{C})$ of maize at the V6, V12, and R2 stages under drought and control conditions. V6, the 6-leaf stage; V12, the 12-leaf stage; R2, the blister stage; +Si, Si addition; -Si, no Si addition; $\mathrm{D}$, drought stress; CK, well-watered control conditions. Data are means \pm standard errors (SE) of three replicates, where $n=3$ for photosynthetic rate (Pn), stomatal conductance $(\mathrm{Sc})$, and transpiration (Tr). Different letters $(\mathrm{a}, \mathrm{b}, \mathrm{c})$ above the bars indicate statistical significance $(p \leq 0.05)$. ${ }^{*}$ Significant at $p \leq 0.01{ }^{*}$ significant at $p \leq 0.05$; NS, no significant difference. 


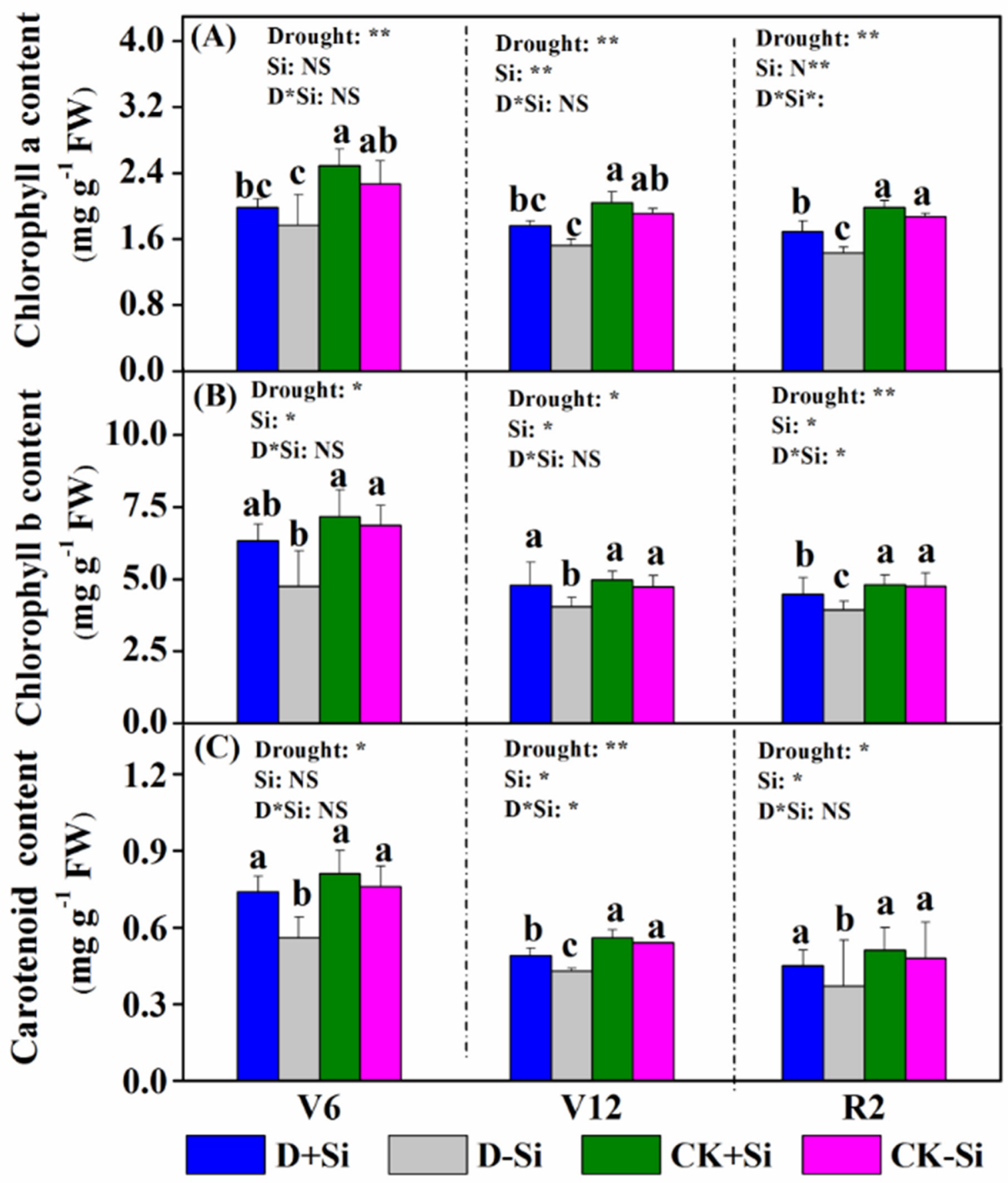

Figure 4. Effect of Si application on chlorophyll a (A), chlorophyll b (B), and carotenoids (C) content in maize leaves at the V6, V12, and R2 stages under drought and control conditions. V6, the 6-leaf stage; V12, the 12-leaf stage; R2, the blister stage; +Si, Si addition; -Si, no Si addition; D, drought stress; CK, well-watered control conditions. Data are the means \pm standard errors (SE) of three replicates, where $n=3$ for chlorophyll content. Different letters $(\mathrm{a}, \mathrm{b}, \mathrm{c})$ above the bars indicate statistical significance $(p \leq 0.05)$. ${ }^{* *}$ Significant at $p \leq 0.01 ;{ }^{*}$ significant at $p \leq 0.05$; NS, no significant difference. 


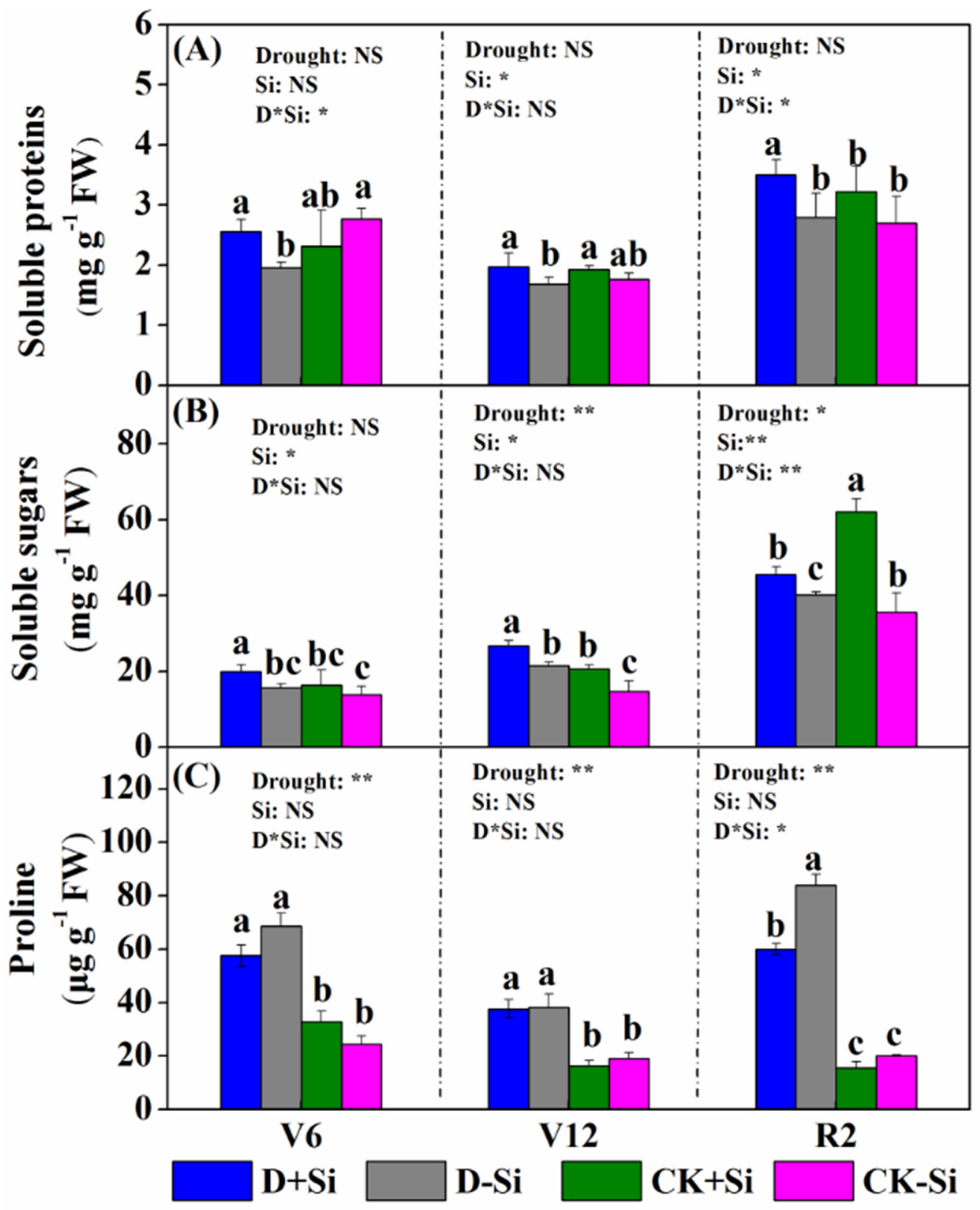

Figure 5. Effect of Si application on soluble protein (A), soluble sugar (B), and proline (C) contents in the maize leaves at the V6, V12, and R2 stages under drought and control conditions. V6, the 6-leaf stage; V12, the 12-leaf stage; R2, the blister stage; +Si, Si addition; -Si, no Si addition; D, drought stress; $\mathrm{CK}$, well-watered controls condition. Data are the means \pm standard errors (SE) of three replicates, where $n=3$ for soluble protein, soluble sugar, and proline contents. Different letters $(\mathrm{a}, \mathrm{b}, \mathrm{c})$ above the bars indicate statistical significance $(p \leq 0.05)$. ${ }^{* *}$ Significant at $p \leq 0.01$; ${ }^{*}$ significant at $p \leq 0.05$; NS, no significant difference. 


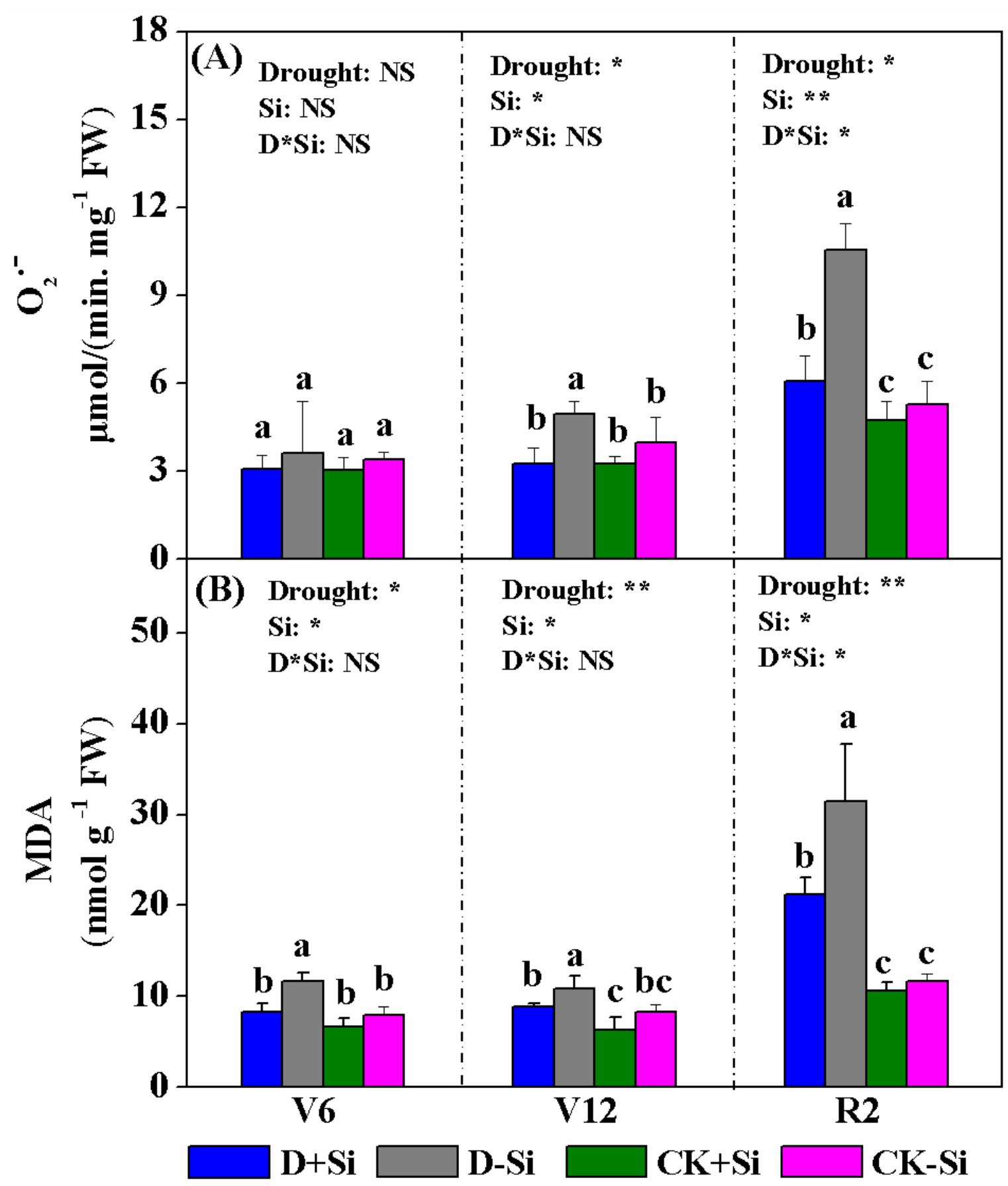

Figure 6. Effect of $\mathrm{Si}$ application on superoxide radical $\left(\mathrm{O}_{2}{ }^{-}, \mathbf{A}\right)$ and MDA $(\mathbf{B})$ contents in the maize leaves at the V6, V12, and R2 stages under drought and control conditions. V6, the 6-leaf stage; V12, the 12-leaf stage; R2, the blister stage; +Si, Si addition; -Si, no Si addition; D, drought stress; CK, well-watered control condition. Data are the means \pm standard errors (SE) of three replicates, where $n=3$ for $\mathrm{O}_{2} \cdot-$ and MDA contents. Different letters $(\mathrm{a}, \mathrm{b}, \mathrm{c})$ above the bars indicate statistical significance $(p \leq 0.05) .{ }^{* *}$ Significant at $p \leq 0.01 ;{ }^{*}$ significant at $p \leq 0.05$; NS, no significant difference.

\subsection{Antioxidant Enzyme Activity}

Drought stress caused an obvious decrease in the activities of superoxide dismutase (SOD), peroxidase (POD), and catalase (CAT), with the exception of SOD at the V6 stage without Si application (Figure 7). Conversely, SOD, POD, and CAT activities were remarkably enhanced by Si application under drought stress (except SOD at the V6 stage), and the D+Si treatments exhibited equivalent 
values of SOD and POD to the corresponding CK treatments. However, no significant differences were observed in the activities of SOD, POD, and CAT regardless of Si treatment under well-watered control conditions. Drought $\times \mathrm{Si}$ interaction was detected as insignificant for SOD, POD, and CAT at each stage.

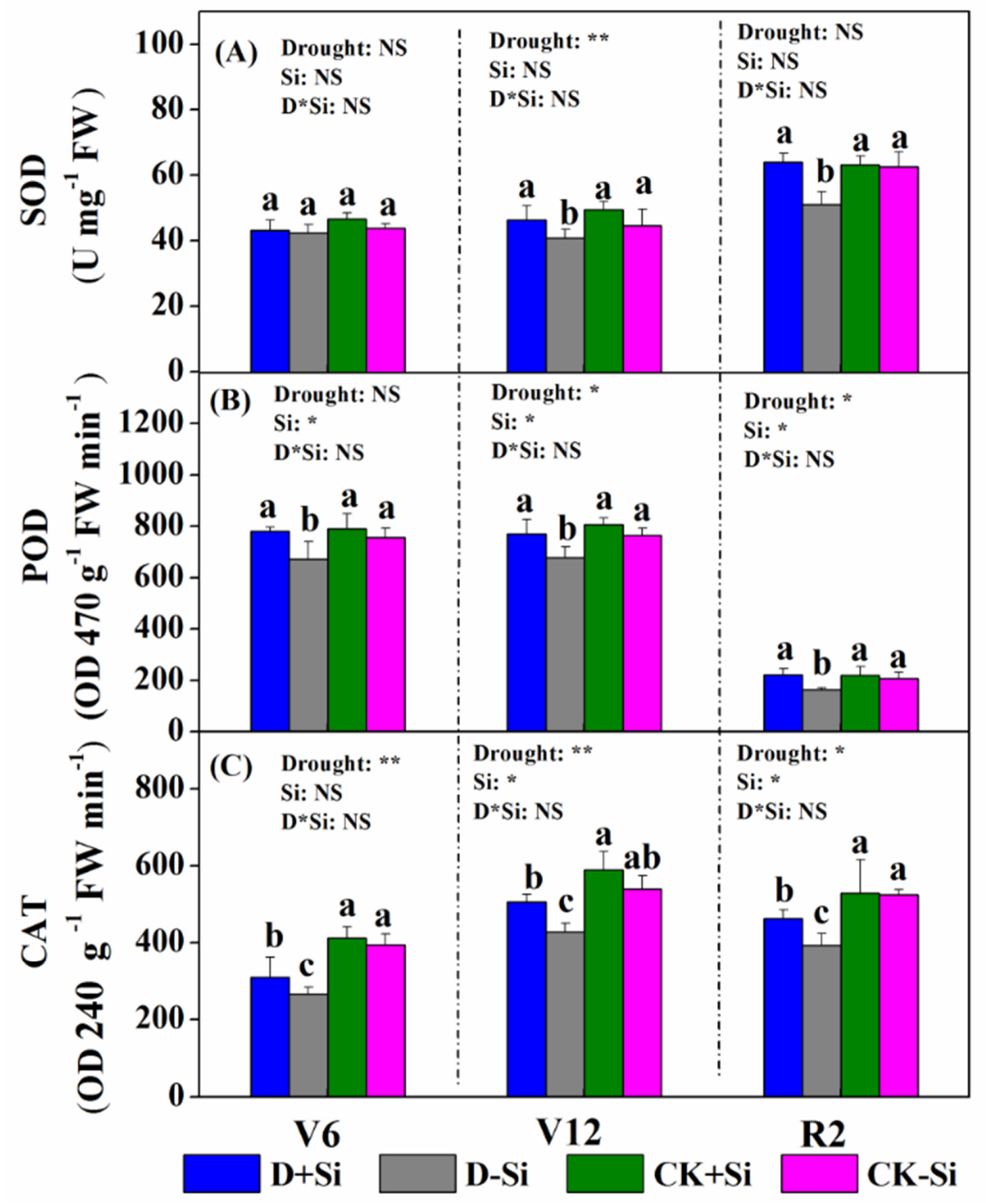

Figure 7. Effect of Si application on SOD (A), POD (B), and CAT (C) activities in the maize leaves at the V6, V12, and R2 stages under drought and control conditions. V6, the 6-leaf stage; V12, the 12-leaf stage; $\mathrm{R} 2$, the blister stage; +Si, Si addition; -Si, no Si addition; D, drought stress; CK, well-watered control condition. Data are the means \pm standard errors (SE) of three replicates, where $n=3$ for SOD, POD, and CAT. Different letters $(\mathrm{a}, \mathrm{b}, \mathrm{c})$ above the bars indicate statistical significance $(p \leq 0.05) .{ }^{* *}$ Significant at $p \leq 0.01 ;{ }^{*}$ significant at $p \leq 0.05 ; \mathrm{NS}$, no significant difference. 


\subsection{Grain Yield}

Irrespective of the stages at which drought stress was imposed, drought stress generally resulted in substantial decreases in maize yields, with the grain yields of the D-V6, D-V12, and D-R2 treatments being $12.9 \%, 28.9 \%$, and $44.8 \%$ lower than the corresponding CK treatments, respectively (Table 2). With the addition of $\mathrm{Si}$, the yields of the D-V6, D-V12, and D-R2 treatments were 18.1\%, 69.8\%, and $80.8 \%$ higher, respectively, than the corresponding treatments without Si additions. Conversely, the straw biomass ranked as $\mathrm{CK} \approx \mathrm{R} 2>\mathrm{V} 12>\mathrm{V} 6$, and the $+\mathrm{Si}$ treatments exhibited a similar straw biomass as the -Si treatments regardless of the growth stages. Additionally, the higher grain yield of the $+\mathrm{Si}$ treatments was accompanied by a high harvest index, and the harvest indices of the studied stages under drought stress imposed at different stages followed the order V6 > V12 > R2.

Table 2. The effect of silicon fertilization and drought stress on maize yield, straw biomass, and the harvest index.

\begin{tabular}{cccc}
\hline Factor & Maize Yield $\left(\mathbf{g ~ p l o t}^{-\mathbf{1}}\right)$ & Straw Biomass $\left(\mathbf{g ~ p l o t}^{-\mathbf{1}}\right)$ & Harvest Index \\
\hline +Si-D-V6 & $190 \pm 6.97 \mathrm{~b}$ & $139 \pm 9.87 \mathrm{c}$ & $0.58 \pm 0.03 \mathrm{a}$ \\
+ Si-D-V12 & $179 \pm 6.66 \mathrm{~b}$ & $166 \pm 5.09 \mathrm{~b}$ & $0.52 \pm 0.02 \mathrm{~b}$ \\
+ Si-D-R2 & $143 \pm 9.95 \mathrm{c}$ & $219 \pm 14.7 \mathrm{a}$ & $0.40 \pm 0.05 \mathrm{~d}$ \\
+Si-CK & $214 \pm 9.19 \mathrm{a}$ & $237 \pm 13.2 \mathrm{a}$ & $0.47 \pm 0.02 \mathrm{bc}$ \\
-Si-D-V6 & $169 \pm 10.3 \mathrm{bc}$ & $135 \pm 6.20 \mathrm{c}$ & $0.55 \pm 0.03 \mathrm{ab}$ \\
-Si-D-V12 & $106 \pm 9.94 \mathrm{~d}$ & $165 \pm 10.7 \mathrm{~b}$ & $0.39 \pm 0.07 \mathrm{~d}$ \\
-Si-D-R2 & $79.1 \pm 8.99 \mathrm{e}$ & $207 \pm 8.61 \mathrm{a}$ & $0.28 \pm 0.01 \mathrm{e}$ \\
-Si-CK & $198 \pm 11.3 \mathrm{ab}$ & $217 \pm 3.97 \mathrm{a}$ & $0.46 \pm 0.02 \mathrm{c}$ \\
Two-Way ANOVA analysis & $* *$ & $\mathrm{NS}$ & $* *$ \\
Silicon (Si) & $* *$ & $* *$ & $* *$ \\
Drought (D) & $* *$ & $\mathrm{NS}$ & $* *$ \\
Si $\times$ Drought & & & $*$
\end{tabular}

Note, The harvest index (HI) was calculated by the total grain weight divided by the above-ground total biomass at the mature stage. Treatment means followed by the different letters are significantly different at $p \leq 0.05 .{ }^{* *}$ Significant at $p \leq 0.01 ; \mathrm{NS}$, no significant difference.

\subsection{Si Concentration in the Plant Tissues and Soil}

Si addition significantly increased Si concentrations in the leaves, stems, and soil across the study periods, with the exception of the stems and soil in the D-V6 treatment (Table 3). As a result, the average Si concentrations in the leaves, stems, and soil of the Si-treated treatments were appreciably higher than the non-Si treatments. Drought stress did not affect Si concentrations in the leaves regardless of Si fertilization.

Table 3. Impact of silicon fertilization and drought stress on Si concentration in maize plants and soil.

\begin{tabular}{cccc}
\hline Factor & Leaf (\%) & Stem (\%) & $\begin{array}{c}\text { Plant-Available Silicon } \\
\text { in the Soil (mg kg }\end{array}$ \\
\hline +Si-D-V6 & $7.84 \pm 0.66 \mathrm{a}$ & $1.49 \pm 0.16 \mathrm{a}$ & $438 \pm 26.8 \mathrm{a}$ \\
+ Si-D-V12 & $7.70 \pm 0.14 \mathrm{a}$ & $1.32 \pm 0.24 \mathrm{ab}$ & $432 \pm 12.9 \mathrm{a}$ \\
+ Si-D-R2 & $7.88 \pm 0.88 \mathrm{a}$ & $1.12 \pm 0.05 \mathrm{bc}$ & $412 \pm 22.7 \mathrm{ab}$ \\
+Si-CK & $8.20 \pm 0.45 \mathrm{a}$ & $1.26 \pm 0.07 \mathrm{abc}$ & $394 \pm 1.60 \mathrm{~b}$ \\
-Si-D-V6 & $6.69 \pm 0.45 \mathrm{~b}$ & $1.45 \pm 0.09 \mathrm{ab}$ & $419 \pm 10.6 \mathrm{a}$ \\
-Si-D-V12 & $6.56 \pm 0.43 \mathrm{~b}$ & $1.01 \pm 0.26 \mathrm{~cd}$ & $375 \pm 17.5 \mathrm{bc}$ \\
-Si-D-R2 & $5.74 \pm 0.86 \mathrm{~b}$ & $0.95 \pm 0.13 \mathrm{~d}$ & $352 \pm 21.3 \mathrm{c}$ \\
-Si-CK & $6.58 \pm 0.55 \mathrm{~b}$ & $1.20 \pm 0.10 \mathrm{bc}$ & $364 \pm 13.3 \mathrm{c}$ \\
Two-Way ANOVA analysis & $* *$ & $*$ & $*$ \\
Silicon (Si) & NS & $*$ & NS \\
Drought (D) & NS & NS & $*$ \\
Si $\times$ Drought & & & \\
\hline
\end{tabular}

Treatment means followed by the different letters are significantly different at $p \leq 0.05$; ${ }^{* *}$ Significant at $p \leq 0.01$; * significant at $p \leq 0.05$; NS, no significant difference. 


\subsection{Correlation Analysis}

The correlation analysis results differed greatly among the three growth stages (Table 4). There were more variables that were significantly correlated with maize yield at the R2 stage than for the V6 and V12 stages. Chlorophyll content, SOD and POD activity, and MDA content were determined to be the most important maize yield indexes due to their significant positive relationships with yield across the treatment periods. Transpiration rate, photosynthetic rate, and CAT were positively and significantly correlated with maize yield at the V12 and R2 stages, but not at the V6 stage. Additionally, proline was significantly negatively correlated with maize yield only at the R2 stage.

Table 4. Pearson correlation analysis between maize yield and selected growth and physiological parameters measured at different growth stages.

\begin{tabular}{cccc}
\hline Parameters & V6 Stage & V12 Stage & R2 Stage \\
\hline Plant height & 0.766 & 0.78 & 0.816 \\
Leaf area & 0.836 & 0.881 & $0.992^{* *}$ \\
Chlorophyll content & $0.924^{*}$ & $0.998^{* *}$ & $0.994^{* *}$ \\
Photosynthetic rate & 0.837 & $0.901^{*}$ & $0.966^{*}$ \\
Transpiration rate & 0.829 & $0.961^{*}$ & $0.987^{*}$ \\
Soluble protein & 0.423 & 0.739 & 0.200 \\
Soluble sugar & 0.162 & 0.137 & 0.521 \\
Proline & -0.674 & -0.755 & $-0.977^{*}$ \\
SOD & $0.918^{*}$ & $0.932^{*}$ & $0.925^{*}$ \\
CAT & 0.831 & $0.976^{*}$ & $0.987^{*}$ \\
POD & $0.971^{*}$ & $0.994^{*}$ & $0.919^{*}$ \\
$\mathrm{O}_{2}{ }^{-}$ & -0.890 & -0.907 & -0.832 \\
MDA & $-0.957^{*}$ & $-0.959^{*}$ & $-0.989^{*}$ \\
\hline
\end{tabular}

** Significant at $p \leq 0.01$; significant at $p \leq 0.05$.

\section{Discussion}

\subsection{Effect of Si on Maize Growth under Drought Stress}

Plant height, leaf area and leaf water content are important morphological indicators for plant growth under drought stress [32]. In the present work, drought stress imposed at different growth stages significantly influenced plant height, leaf area and leaf water content. However, plant height and leaf area between the D-V6 and CK treatments did not differ, indicating compensatory growth in the D-V6 treatment after re-watering. Similar results that maize growth recovered rapidly from drought stress when imposed at the early vegetative stage were reported [19]. Drought stress imposed at the R2 stage also significantly reduced leaf area in this study. This finding is consistent with a previous report where water deficit at both the vegetative and reproductive stages decreased leaf area in maize [33]. However, Mansouri-Far et al. (2010) did not observe any differences in leaf area in maize under drought stress imposed at the R3 stage [18]. This discrepancy may be associated with the differences in the duration and degree of drought stress, as well as the varying temperature and soil environments.

Si addition had little effect on plant height, leaf area and leaf water content under drought stress at the V6 stage. This was in contrast to our observations at the V12 and R2 stages where leaf area and leaf water content significantly increased (Figure 2). This could be attributed to the improved root water uptake and increased chlorophyll levels as a result of Si application under water deficit at the late growth stage (Figure 4). This finding is consistent with studies of Gong et al. (2008) in wheat [34] and Maillard et al. (2018) in barley [35]. Additionally, Si concentrations in the leaves were substantially enhanced by Si addition during the late growth stages (Table 3). This could promote the accumulation of photoliths in the leaf veins, thus providing better support to the leaf under drought stress [36,37]. Additionally, Yin et al. (2014) demonstrated that Si induced an increase in polyamine levels, which is beneficial for delaying the leaf senescence caused by water deficit in sorghum [12]. 
Our findings also suggested that $\mathrm{Si}$ addition had a better effect on maize resistance to drought stress at the reproductive stage than at the early vegetative stage. This might be because maize is relatively insensitive to water deficit during the early vegetative stage [32], and thus 50\% field capacity is not sufficient to determine the role that Si plays in soil water deficit tolerance at this stage.

\subsection{Effect of Si on Photosynthesis under Drought Stress}

Maintaining a high photosynthetic rate is an important characteristic of drought resistance for plants [38]. Irrespective of the growth stage that drought stress was imposed at, it substantially hampered maize photosynthetic rate, transpiration rate, and stomatal conductance in the present study. However, Si application significantly alleviated these decreases at the V12 and R2 stages (Figure 3). Similar phenomena have also been observed in some other plant species, including soybean [10], rice [11], and Glycyrrhiza [39]. We speculate that Si supplementation allowed the drought-stressed plants to maintain high leaf water and chlorophyll contents, thus improving photosynthesis. Gong et al. (2012) reported that $\mathrm{Si}$ application increased the activity of the photosynthetic enzymes that are involved in the Si-induced regulation of photosynthesis in wheat under drought stress [40].

Transpiration rate and stomatal conductance are two important factors affecting plant-water relations [41]. In this study, drought stress resulted in a significant inhibition of transpiration rate and stomatal conductance, which corroborates previous reports in wheat and dry bean (Phaseolus spp.) [42]. However, Si fertilization strongly increased transpiration rate and stomatal conductance under drought stress imposed at the V12 and R2 stages. These findings are consistent with previous studies where Si application enhanced crop root water uptake and increased stomatal conductance under drought stress [14,40]. Liu et al. (2014) recently demonstrated that Si-induced increases in transpiration rate and stomatal conductance were associated with increased root hydraulic conductance resulting from the up-regulation of aquaporins under drought stress [43]. In contrast, some other studies attribute the enhanced water use efficiency under Si treatments to decreased leaf transpiration $[44,45]$. Further studies are thus required to elucidate the regulatory roles of Si on water uptake and transport across entire plants. Furthermore, plant water status was shown to be another factor that determined the responses of stomatal conductance to drought stress [46]. Therefore, physiological responses that depend on moisture content of leaves and soils will be fully considered in our further experiments.

\subsection{Effect of Si on Osmotic Adjustment under Drought Stress}

Plants accumulate organic solutes in the cytoplasm, such as proline, glycine-betaine, glucose, and fructose, in response to drought stress [47]. Soluble sugar and protein increased remarkably as a result of $\mathrm{Si}$ application across the study period, especially under drought-stressed conditions. According to Sonobe et al. (2009), soluble sugar is an indicator of osmotic adjustment capacity under drought stress as it improves root water uptake [48]. Therefore, the enhancement of soluble sugar and protein may be one of the primary underlying mechanisms for the mitigation of drought stress damage by Si. A similar result was reported by Latef and Tran (2016), who also found that the increase in soluble sugars and proteins in maize leaves induced by $\mathrm{Si}$ application enhanced photosynthetic activity under alkaline stress [49].

Proline acts as a signaling molecule under stressful conditions [50]. In the present study, drought stress significantly increased the proline content in the maize leaves. The effects of $\mathrm{Si}$ supplementation on proline accumulation varied among the studied drought stages, having little impact on proline content at the V6 and V12 stages but significantly decreasing proline content at the R2 stage. This suggests that high levels of proline are not required for the mitigation of drought stress by Si. Pei et al. (2010) demonstrated a significant negative relationship between proline content and both shoot dry weight and leaf chlorophyll content in wheat seedlings that were supplemented with Si under PEG (polyethylene glycol)-induced drought stress [51]. 


\subsection{Effect of Si on Antioxidant Defense under Drought Stress}

Drought stress could increase oxygen-induced cellular damage and increase MDA accumulation due to the enhanced production of reactive oxygen species (ROS) [41]. Antioxidant enzymes, such as SOD, POD, and CAT, typically contribute to the alleviation of ROS-induced damage to the cell membrane system in plants [47]. In this work, we found that drought stress significantly decreased SOD, POD, and CAT activities and increased the accumulation of MDA and $\mathrm{O}_{2}{ }^{--}$in maize leaves. However, the application of Si strongly increased the activities of SOD, POD, and CAT, thereby reducing the MDA and $\mathrm{O}_{2}{ }^{--}$concentrations in the plants. Thus, Si has a beneficial role in maintaining cell membrane integrity and lowering cell membrane permeability by maintaining high antioxidant enzyme activity [52]. Similar findings under similar experimental conditions were also observed in wheat [8], soybean [10], and tomato [53]. There existed increasing evidence that $\mathrm{Si}$ mitigates oxidative stress by reducing antioxidant enzyme activities and improving water uptake of plants [54]. Our results further demonstrated that $\mathrm{Si}$ effectively enhanced the antioxidant enzyme activities, and decreased MDA and $\mathrm{O}_{2}{ }^{\cdot-}$ concentrations in maize plants, indicating that $\mathrm{Si}$ is one of the most important exogenous factors to improve drought resistance capability of maize [55].

\subsection{Effect of Si on Maize Biomass and Yield under Drought Stress}

Many studies have demonstrated that the occurrence of water deficit during the vegetative and reproductive stages is associated with increased yield reduction during the early vegetative stage [19]. Our study corroborated this, in which drought stress imposed during the R2 stage resulted in the largest yield reduction, followed by the V12 stage and then the V6 stage. The harvest index followed the same pattern. Pandey et al. (2000) suggested that drought stress occurring only once during the vegetative stage induced root extension deep into the soil, increasing water uptake from the deep layer and resulting in a higher relative yield after re-watering [32].

Supplementation with Si efficiently mitigates the yield losses caused by water deficit, particularly at the V12 and R2 stages, indicating significant potential for $\mathrm{Si}$ in the mitigation of yield reduction caused by drought stress, especially when drought occurs during the late vegetative and reproductive stages. This is similar to the findings of Lavinsky et al. (2016), who reported that the positive effect of $\mathrm{Si}$ on rice production was manifested when it was specifically applied during the reproductive stage [56]. According to Tollenaar et al. (2004) [57] and Detmann et al. (2012) [58], Si-induced higher grain yields might be associated with increased green leaf area and photosynthesis under Si application (Figure 2B; Figure 3A). The correlation analysis indicated that chlorophyll content, SOD and POD activity, and MDA content constituted the most important indicators of maize yield due to their significant correlations with yield across the drought stages. The increased number of variables that were significantly correlated with maize yield in the R2 stage in comparison with the V6 and V12 stages supports the conclusion that the reproductive stage of maize is more sensitive to drought stress and, thus, the beneficial role of $\mathrm{Si}$ in alleviating drought-induced yield reduction was more evident when drought was imposed during the early reproductive stage.

\section{Conclusions}

Drought stress, irrespective of the imposed stages (V6, V12, and R2 stages), markedly decreased leaf area, photosynthetic rate, transpiration, stomatal conductance, chlorophyll content, and antioxidant activities, but enhanced lipid peroxidation, thus resulting in a substantial reduction in maize yields. Drought stress at the R2 stage resulted in increased yield reduction in comparison with the V12 and V6 stages, indicating that reproductive development is more sensitive to drought than vegetative development. However, $\mathrm{Si}$ addition could alleviate the adverse effects of drought stress through increasing leaf area, photosynthetic rate, chlorophyll content, antioxidant activities, and ultimately, grain yield, particularly when drought stress occurs at the V12 and R2 stages. Maize yield was significantly and positively correlated with chlorophyll content and SOD, POD, and CAT activity, 
indicating that $\mathrm{Si}$-induced changes in chlorophyll content and antioxidant activity might be an important mitigatory mechanism for drought stress in maize.

Author Contributions: Conceptualization, D.N., A.D., and Z.L. (Zhanjun Liu); methodology, A.Q.; software, B.Z.; investigation, D.N., Z.L. (Zugui Liu); resources, J.Z.; data curation, D.N., A.Q, and Z.L. (Zhandong Liu); Funding acquisition, D.N., J.X.; writing—original draft preparation, D.N., A.Q., and Z.L. (Zhanjun Liu); writing—review and editing, A.Q. All authors have read and agreed to the published version of the manuscript.

Funding: This work was jointly supported by the National Key Research and Development Program of China (2017YFD0301102), the Central Public-Interest Scientific Institution Basal Research Fund (Farmland Irrigation Research Institute, CAAS, FIRI2017-01, FIRI2017-05, FIRI2020-02), the Agriculture Research System of China (CARS-02), and the Special Fund for Agro-scientific Research in the Public Interest (201503130).

Acknowledgments: The authors sincerely thank the anonymous editors and reviewers for their valuable comments and suggestions that helped improve the quality of this manuscript.

Conflicts of Interest: The authors declare no conflict of interest.

\section{References}

1. Vurukonda, S.S.K.P.; Vardharajula, S.; Shrivastava, M.; SkZ, A. Enhancement of drought stress tolerance in crops by plant growth promoting rhizobacteria. Microbiol. Res. 2016, 184, 13-24. [CrossRef]

2. Hussain, M.; Farooq, S.; Hasan, W.; Ul-Allah, S.; Tanveer, M.; Farooq, M.; Nawaz, A. Drought stress in sunflower: Physiological effects and its management through breeding and agronomic alternatives. Agric. Water Manag. 2018, 201, 152-166. [CrossRef]

3. Vinocur, B.; Altman, A. Recent advances in engineering plant tolerance to abiotic stress, achievements and limitations. Curr. Opin. Biotechnol. 2005, 16, 123-132. [CrossRef]

4. Mancosu, N.; Snyder, R.L.; Kyriakakis, G.; Spano, D. Water scarcity and future challenges for food production. Water 2015, 7, 975-992. [CrossRef]

5. Ning, D.F.; Song, A.L.; Fan, F.L.; Li, Z.J.; Liang, Y.C. Effects of slag-based silicon fertilizer on rice growth and brown-spot resistance. PLoS ONE 2014, 9, e102681. [CrossRef] [PubMed]

6. Ma, J.F.; Yamaji, N. A cooperative system of silicon transport in plants. Trends Plant Sci. 2015, 20, 435-442. [CrossRef] [PubMed]

7. Conceicao, S.S.; Neto, C.F.D.; Marques, E.C.; Barbosa, A.V.C.; Galvao, J.R.; de Oliveira, T.B.; Okumura, R.S.; Martins, J.T.D.; Costa, T.C.; Gomes, E. Silicon modulates the activity of antioxidant enzymes and nitrogen compounds in sunflower plants under salt stress. Arch. Agron. Soil Sci. 2019, 65, 1237-1247. [CrossRef]

8. Gong, H.J.; Zhu, X.Y.; Chen, K.M.; Wang, S.M.; Zhang, C.L. Silicon alleviates oxidative damage of wheat plants in pots under drought. Plant Sci. 2005, 169, 313-321. [CrossRef]

9. Gao, X.; Zou, C.; Wang, L.; Zhang, F. Silicon decreases transpiration rate and conductance from stomata of maize plants. J. Plant Nutr. 2006, 29, 1637-1647. [CrossRef]

10. Shen, X.F.; Zhou, Y.Y.; Duan, L.S.; Li, Z.H.; Eneji, A.E.; Li, J.M. Silicon effects on photosynthesis and antioxidant parameters of soybean seedlings under drought and ultraviolet-B radiation. Silicon effects on photosynthesis and antioxidant parameters of soybean seedlings under drought and ultraviolet-B radiation. J. Plant Physiol. 2010, 167, 1248-1252. [CrossRef]

11. Chen, W.; Yao, X.Q.; Cai, K.Z.; Chen, J.N. Silicon alleviates drought stress of rice plants by improving plant water status, photosynthesis and mineral nutrient absorption. Biol. Trace Elem. Res. 2011, 142, 67-76. [CrossRef]

12. Yin, L.N.; Wang, S.W.; Liu, P.; Wang, W.H.; Cao, D.; Deng, X.P. Silicon-mediated changes in polyamine and 1-aminocyclopropane-1-carboxylic acid are involved in silicon-induced drought resistance in Sorghum bicolor. Plant Physiol. Bioch. 2014, 80, 268-277. [CrossRef]

13. Helaly, M.N.; Hoseiny, E.H.; El-Sheery, N.I.; Rastogi, A.; Kalaji, H.M. Regulation and physiological role of silicon in alleviating drought stress of mango. Plant Physiol. Bioch. 2017, 118, 31-44. [CrossRef]

14. Hattori, T.; Inanaga, S.; Araki, H.; An, P.; Morita, S.; Luxova, M.; Lux, A. Application of silicon enhanced drought tolerance in Sorghum bicolor. Physiol. Plantarum. 2005, 123, 459-466. [CrossRef] 
15. Kim, Y.H.; Khan, A.L.; Waqas, M.; Lee, I.J. Silicon regulates antioxidant activities of crop plants under abiotic-induced oxidative stress, A review. Front. Plant Sci. 2017, 8, 1346. [CrossRef]

16. Agarie, S.; Uchida, H.; Agata, W.; Kubota, F.; Kaufman, P.B. Effects of silicon on transpiration and leaf conductance in rice plants (Oryza sativa L.). Plant Prod. Sci. 1998, 1, 89-95. [CrossRef]

17. Sun, Q.; Liang, X.L.; Zhang, D.G.; Li, X.H.; Hao, Z.F.; Weng, J.F.; Li, M.S.; Zhang, S.H. Trends in drought tolerance in Chinese maize cultivars from the 1950s to the 2000s. Field Crops Res. 2017, 201, 175-183. [CrossRef]

18. Mansouri-Far, C.; Sanavy, S.A.M.M.; Saberali, S.F. Maize yield response to deficit irrigation during low-sensitive growth stages and nitrogen rate under semi-arid climatic conditions. Agric. Water Manag. 2010, 97, 12-22. [CrossRef]

19. Comas, L.H.; Trout, T.J.; DeJonge, K.C.; Zhang, H.H.; Gleason, S.M. Water productivity under strategic growth stage-based deficit irrigation in maize. Agric. Water Manag. 2019, 212, 433-440. [CrossRef]

20. Trout, T.J.; DeJonge, K.C. Water productivity of maize in the US high plains. Irrig. Sci. 2017, 35, 251-266. [CrossRef]

21. Wang, Y.; Zhang, X.Y.; Chen, J.; Chen, A.J.; Wang, L.Y.; Guo, X.Y.; Niu, Y.L.; Liu, S.R.; Mi, G.H.; Gao, Q. Reducing basal nitrogen rate to improve maize seedling growth, water and nitrogen use efficiencies under drought stress by optimizing root morphology and distribution. Agric. Water Manag. 2019, 212, 328-337. [CrossRef]

22. Malcovska, S.M.; Ducaiova, Z.; Backor, M. Impact of silicon on maize seedlings exposed to short-term UV-B irradiation. Biologia 2014, 69, 1349-1355.

23. Li, H.S. Principles and Techniques of Plant Physiological Biochemical Experiment; Higher Education Press: Beijing, China, 2000. (In Chinese)

24. Dhindsa, R.S.; Plumb-Dhindsa, P.; Thorpe, T.A. Leaf senescence, correlated with increased levels of membrane permeability and lipid peroxidation, and decreased levels of superoxide dismutase and catalase. J. Exp. Bot. 1981, 132, 93-101. [CrossRef]

25. Elstner, E.F.; Heupel, A. Inhibition of nitrite formation from hydroxylammonium chloride, a simple assay for superoxide dismutase. Anal. Biochem. 1976, 70, 616-620. [CrossRef]

26. Bates, I.; Waldren, R.P.; Teare, J.D. Rapid determination of free proline for water stress studies. Plant Soil 1973, 39, 205-207. [CrossRef]

27. Sgherri, C.L.M.; Loggini, B.; Puliga, S.; Navari-Izzo, F. Antioxidant system in Sporobolus stapfianus, changes in response to desiccation and rehydration. Phytochemistry 1994, 35, 561-565. [CrossRef]

28. Aebi, H. Catalase in vitro. Methods Enzymol. 1984, 105, 121-127.

29. Chance, B.; Maehly, A.C. Assay of catalases and peroxidases. Methods Enzymol. 1955, 2, 764-775.

30. Lu, R.K. Analytical Methods for Soil and Agro-Chemistry; Science and Technology Publishing House: Beijing, China, 2000. (In Chinese)

31. Dai, W.M.; Zhang, K.Q.; Duan, B.W. Rapid determination of silicon content in rice (Oryzasativa L). Chin. J. Rice Sci. 2005, 19, 460-462. (In Chinese)

32. Cakir, R. Effect of water stress at different development stages on vegetative and reproductive growth of corn. Field Crop Res. 2004, 89, 1-16. [CrossRef]

33. Pandey, J.R.K.; Maranville, P.J.W.; Chetim, M.M. Deficit irrigation and nitrogen effects on maize in a Sahelian environment II. Shoot growth, nitrogen uptake and water extraction. Agric. Water Manag. 2000, 46, 15-27. [CrossRef]

34. Gong, H.J.; Chen, K.M.; Zhao, Z.G.; Chen, G.C.; Zhou, W.J. Effects of silicon on defense of wheat against oxidative stress under drought at different developmental stages. Biologia. Plantarum. 2008, 52, 592-596. [CrossRef]

35. Maillard, A.; Ali, N.; Schwarzenberg, A.; Jamois, F.; Yvin, J.C.; Hosseini, S.A. Silicon transcriptionally regulates sulfur and $\mathrm{ABA}$ metabolism and delays leaf senescence in barley under combined sulfur deficiency and osmotic stress. Environ. Exp. Bot. 2018, 155, 394-410. [CrossRef]

36. Song, A.; Ning, D.F.; Fan, F.L.; Li, Z.J.; Provance-Bowley, M.; Liang, Y.C. The potential for carbon bio-sequestration in China's paddy rice (Oryza sativa L.) as impacted by slag-based silicate fertilizer. Sci. Rep. 2015, 5, 17354. [CrossRef] 
37. Meunier, J.D.; Barboni, D.; Anwar-ul-Haq, M.; Levard, C.; Chaurand, P.; Vidal, V.; Grauby, O.; Huc, R.; Laffont-Schwob, I.; Rabier, J. Effect of phytoliths for mitigating water stress in durum wheat. New Phytol. 2017, 215, 229-239. [CrossRef]

38. Cattivelli, L.; Rizza, F.; Badeck, F.W.; Mazzucotelli, E.; Mastrangelo, A.M.; Francia, E.; Mare, C.; Tondelli, A.; Stanca, A.M. Drought tolerance improvement in crop plants, an integrated view from breeding to genomics. Field Crops Res. 2008, 105, 1-14. [CrossRef]

39. Zhang, W.J.; Xie, Z.C.; Wang, L.H.; Li, M.; Lang, D.Y.; Zhang, X.H. Silicon alleviates salt and drought stress of Glycyrrhiza uralensis seedling by altering antioxidant metabolism and osmotic adjustment. J. Plant Res. 2017, 130, 611-624. [CrossRef]

40. Gong, H.J.; Chen, K.M. The regulatory role of silicon on water relations, photosynthetic gas exchange, and carboxylation activities of wheat leaves in field drought conditions. Acta Physiol. Plant. 2012, 34, 1589-1594. [CrossRef]

41. Farooq, M.; Wahid, A.; Kobayashi, N.; Fujita, D.; Basra, S.M.A. Plant drought stress, effects, mechanisms and management. Agron. Sustain. Dev. 2009, 29, 185-212. [CrossRef]

42. Mahmood, S.; Daur, I.; Hussain, M.B.; Nazir, Q.; Al-Solaimani, S.G.; Ahmad, S.; Bakhashwain, A.A.; Elsafor, A.K. Silicon application and rhizobacterial inoculation regulate mung bean response to saline water irrigation. Clean-Soil Air Water 2017, 45, 1600436. [CrossRef]

43. Liu, P.; Yin, L.N.; Deng, X.P.; Wang, S.W.; Tanaka, K.; Zhang, S.Q. Aquaporin-mediated increase in root hydraulic conductanceis involved in silicon-induced improved root water uptake under osmotic stress in Sorghum bicolor L. J. Exp. Bot. 2014, 65, 4747-4756. [CrossRef]

44. Gong, H.J.; Chen, K.M.; Chen, G.C.; Wang, S.M.; Zhang, C.L. Effects of silicon on growth of wheat under drought. J. Plant Nutr. 2003, 26, 1055-1063. [CrossRef]

45. Gao, X.; Zou, C.; Wang, L.; Zhang, F. Silicon improves water use efficiency in maize plants. J. Plant Nutr. 2004, 27, 1457-1470. [CrossRef]

46. Puértolas, J.; Albacete, A.; Dodd, I.C. Irrigation frequency transiently alters whole plant gas exchange, water and hormone status, but irrigation volume determines cumulative growth in two herbaceous crops. Environ. Exp. Bot. 2020, 176, 104101. [CrossRef]

47. Rao, D.E.; Chaitanya, K.V. Photosynthesis and antioxidative defense mechanisms in deciphering drought stress tolerance of crop plants. Biol. Plantarum. 2016, 60, 201-218. [CrossRef]

48. Sonobe, K.; Hattori, T.; An, P.; Tsuji, W.; Eneji, E.; Tanaka, K.; Inanaga, S. Diurnal variations in photosynthesis, stomatal conductance and leaf water relation in sorghum grown with or without silicon under water stress. J. Plant Nutr. 2009, 32, 433-442. [CrossRef]

49. Latef, A.A.A.; Tran, L.S.P. Impacts of priming with silicon on the growth and tolerance of maize plants to alkaline stress. Front. Plant Sci. 2016, 7, 243.

50. Mansour, M.M.F.; Ali, E.F. Evaluation of proline functions in saline conditions. Phytochemistry 2017, 140, 52-68. [CrossRef]

51. Pei, Z.F.; Ming, D.F.; Liu, D.; Wan, G.L.; Geng, X.X.; Gong, H.J.; Zhou, W.J. Silicon improves the tolerance to water-deficit stress induced by polyethylene glycol in wheat (Triticum aestivum L.) seedlings. J. Plant Growth Regul. 2010, 29, 106-115. [CrossRef]

52. Coskun, D.; Britto, D.T.; Huynh, W.Q.; Kronzucker, H.J. The role of silicon in higher plants under salinity and drought stress. Front. Plant Sci. 2016, 7, 1072. [CrossRef]

53. Shi, Y.; Zhang, Y.; Yao, H.J.; Wu, J.W.; Sun, H. Silicon improves seed germination and alleviates oxidative stress of bud seedlings in tomato under water deficit stress. Plant Physiol. Bioch. 2014, 78, 27-36. [CrossRef] [PubMed]

54. Kang, J.; Zhao, W.; Zhu, X. Silicon improves photosynthesis and strengthens enzyme activities in the $\mathrm{C}_{3}$ succulent xerophyte zygophyllum xanthoxylum under drought stress. J. Plant Physiol. 2016, 199, 76-86. [CrossRef] [PubMed]

55. Puértolas, J.; Larsen, E.K.; Davies, W.J.; Dodd, I.C. Applying 'drought' to potted plants by maintaining suboptimal soil moisture improves plant water relations. J. Exp. Bot. 2017, 68, 2413-2424. [CrossRef]

56. Lavinsky, A.O.; Detmann, K.C.; Reis, J.V.; Avila, R.T.; Sanglard, M.L.; Pereira, L.F.; Sanglard, L.M.V.P.; Rodrigues, F.A.; Araujo, W.L.; DaMatta, F.M. Silicon improves rice grain yield and photosynthesis specifically when supplied during the reproductive growth stage. J. Plant Physiol. 2016, 206, 125-132. [CrossRef] 
57. Tollenaar, M.; Ahmadzadeh, A.; Lee, E.A. Physiological basis of heterosis for grain yield in maize. Crop Sci. 2004, 44, 2086-2094. [CrossRef]

58. Detmann, K.C.; Araujo, W.L.; Martins, S.C.V.; Sanglard, L.M.V.P.; Reis, J.V.; Detmann, E.; Rodrigues, F.A.; Nunes-Nesi, A.; Fernie, A.R.; DaMatta, F.M. Silicon nutrition increases grain yield, which, in turn, exerts a feed-forward stimulation of photosynthetic rates via enhanced mesophyll conductance and alters primary metabolism in rice. New Phytol. 2012, 196, 752-762. [CrossRef] 